\title{
THE ANATOMICAL SOURCE OF TRAIL SUBSTANCES IN FORMICINE ANTS ${ }^{1}$
}

\author{
By M. S. BLUM ${ }^{2}$ AND E. O. WILSON ${ }^{3}$
}

Carthy (I95I) showed that when workers of the formicine ant Lasius fuliginosus (Latreille) lay odor trails, they emit minute streaks of liquid that can be made visible to the naked eye by dusting with lycopodium power. By tracing food marked with edible charcoal, Carthy further proved that at least some of the liquid comes from the hind gut. He concluded that the trail substance is produced by the hind gut, probably as a component of the ingested gut contents rather than as a special secretion of the gut walls. In fact, this conclusion does not necessarily follow from the experimental results. It is equally possible that the critical trail substance is produced by another organ (e. g. the poison glands) and added to the anal streak. The necessity of considering such an alternative has been impelled by the discovery in recent years that the trail substances of certain non-formicine species are powerful attractants generated as glandular secretions in trace amounts (Wilson, 1963).

Nevertheless, even though Carthy's original evidence was not definitive, it now appears probable that his conclusion is basically correct. Using the artificial trail technique (Wilson, 1959), which allows a more certain identification of the anatomical source, we have been able to establish that in two other formicine species, Myrmelachista ramulorum Wheeler and Paratrechina longicornis (Latreille), the hind gut is the true primary source. Since no nonformicine ant species investigated thus far shares the character, the interesting possibility is raised that the hind-gut source is a unique evolutionary innovation of the Formicinae.

\section{Procedure and Results}

Myrmelachista ramulorum. The workers of this species form some of the longest and most conspicuous trail formations found in the Formicinae. At Mayaguez, Puerto Rico, where the species is abundant, it was noted that workers following trails frequently touched

\footnotetext{
${ }^{1}$ This work was supported in part by National Science Foundation Grants G22074, G19200 and a grant from the University Council on Research of Louisiana State University.

${ }^{2}$ Department of Entomology, Louisiana State University, Baton Rouge, Louisiana.

${ }^{3}$ Biological Laboratories, Harvard University, Cambridge, Massachusetts. Manuscript received by the editor November 12, 1963.
} 
Table I. Response of Myrmelachista ramulorum workers to artificial trails prepared from three abdominal organs.

$\begin{array}{lcc}\text { Organ } & \text { No. of workers tested } & \text { No. of workers responding } \\ \begin{array}{l}\text { Poison gland } \\ \text { (plus vesicle) }\end{array} & 180 & 6 \\ \text { Accessory gland } & \mathrm{I} 80 & 0 \\ \text { Hind gut } & \mathrm{I} 8 \mathrm{O} & \mathrm{I} 6 \mathrm{I}\end{array}$

the tips of their gasters to the substrate. This indicated the possibility that the trail substance is secreted from some abdominal organ. In experiments conducted by Blum in 1963, artificial trails were made by streaking single organs and their contents onto a piece of paper in the form of a circle six inches in diameter. Groups of 20 living ramulorum workers were then quickly introduced onto the center of the circle and their movements followed. If an ant, upon encountering the circle, proceeded to follow it closely at least once through its entire circumference, a positive response was recorded. The principal terminal abdominal organs were tested in this fashion. The results of six replications are given in Table $\mathrm{I}$. They show clearly that the hind gut is at least a major source of the trail substance. In supplementary experiments, artificial trails prepared from the hind gut of Myrmelachista were also tested on workers of the following species: the myrmicines Solenopsis geminata (Fabricius) and Pheidole fallax Mayr, the dolichoderines Tapinoma melanocephalum (Fabricius) and Iridomyrmex melleus Wheeler, and the formicine Paratrechina longicornis. The results were all completely negative.

Paratrechina longicornis. This pantropical species is well known both for the efficiency of its recruitment trails and the length and complexity of its persistent trunk trails. In experiments conducted by Wilson at Bacolet, Tobago, in 196I, workers were first attracted in large numbers to sugar baits. Artificial trails were then led from the periphery of the feeding groups outward for a distance of 30 centimeters. A positive response was recorded if an ant followed the trail to at least its midpoint. Control experiments using trails of tap water produced entirely negative results. In the experimental trails, all of the major organs located in the posterior half of the abdomen were tested. The results are given in Table 2. They identify the hind gut as the primary immediate source of the trail substance.

\section{Discussion}

Our results do not disclose whether the pheromone is produced as a 
Table 2. Response of Paratrechina longicornis workers to artificial trails prepared from four abdominal organs.

\begin{tabular}{|c|c|c|c|}
\hline Organ & $\begin{array}{l}\text { No. of } \\
\text { replications }\end{array}$ & $\begin{array}{l}\text { No. of workers } \\
\text { responding }\end{array}$ & $\begin{array}{l}\text { Duration of } \\
\text { response to } \\
\text { nearest } 1 / 2 \text { min. }\end{array}$ \\
\hline $\begin{array}{l}\text { Poison gland } \\
\text { (plus vesicle) }\end{array}$ & 8 & $\mathrm{O}, \mathrm{O}, \mathrm{O}, \mathrm{O}, \mathrm{O}, \mathrm{O}, \mathrm{O}, \mathrm{I}$ & $\mathrm{I} / 2$ \\
\hline Accessory gland & 8 & all o & \\
\hline Hind gut & 8 & $\begin{array}{l}\mathrm{O}, 4,8,8, \mathrm{I} \mathrm{I}, \mathrm{I} 5 \\
3 \mathrm{I}, 37+\end{array}$ & $\begin{array}{l}\mathrm{O}, \mathrm{I} 1 / 2, \mathrm{I} / 2,2 \mathrm{I} / 2, \mathrm{I}, \\
2,7 \mathrm{r} / 2,2 \mathrm{O}+\end{array}$ \\
\hline Ovary & 8 & all o & \\
\hline Control (water) & 8 & all o & $\longrightarrow$ \\
\hline
\end{tabular}

side product of digestion or as a special secretion of the gut wall. Examination of the freshly dissected gut wall under low power with a light microscope failed to reveal obvious glandular tissue that could serve as a possible source. But this is in itself quite inconclusive, since inconspicuous unicellular glands are known to abound elsewhere in the ant body. Also, the data do not reveal whether the trail substance is actually manufactured in the hind gut, or whether it is produced forward of the hind gut and passed - perhaps in precursor form - back with the gut contents. The solution of these questions awaits the development of a finer dissection technique than the one used in the present study.

These preliminary results have an important phylogenetic implication. All seven non-formicine genera on which similar experiments have been conducted (Solenopsis, Pheidole, Tetramorium, Acromyrmex, Atta, Iridomyrmex, Monacis; see Wilson, 1963) secrete trail substances from glands not associated with the hind gut. Moreover, the two formicine species reported here belong to widely different branches of the subfamily: Myrmelachista constitutes a tribe by itself within Emery's section Alloformicinae, while Paratrechina is a member of the tribe Lasiini of the section Euformicinae. No member of the third formicine section, the Heteroformicinae (consisting of the tribes Myrmecorhynchini and Myrmoteratini) has been investigated. It will be of interest to see whether trail-laying species in other formicine genera and tribes also use the hind gut as a primary source.

Carthy, J. D.

\section{Literature Cited}

1951. The orientation of two allied species of British ant. II. Odour trail laying and following in Acanthomyops (Lasius) fuliginosus. Behaviour, 3 :304-318. 
EMERY, C.

1925. Hymenoptera: Fam. Formicidae, Subfam. Formicinae. Genera Insect. (Wytsman), 183:1-302.

WiLson, E. O.

1959. Source and possible nature of the odor trail of the fire ant Solenopsis saevissima (Fr. Smith). Science, 129:643-644.

1963. The social biology of ants. Ann. Rev. Entomol., 8:345-368. 

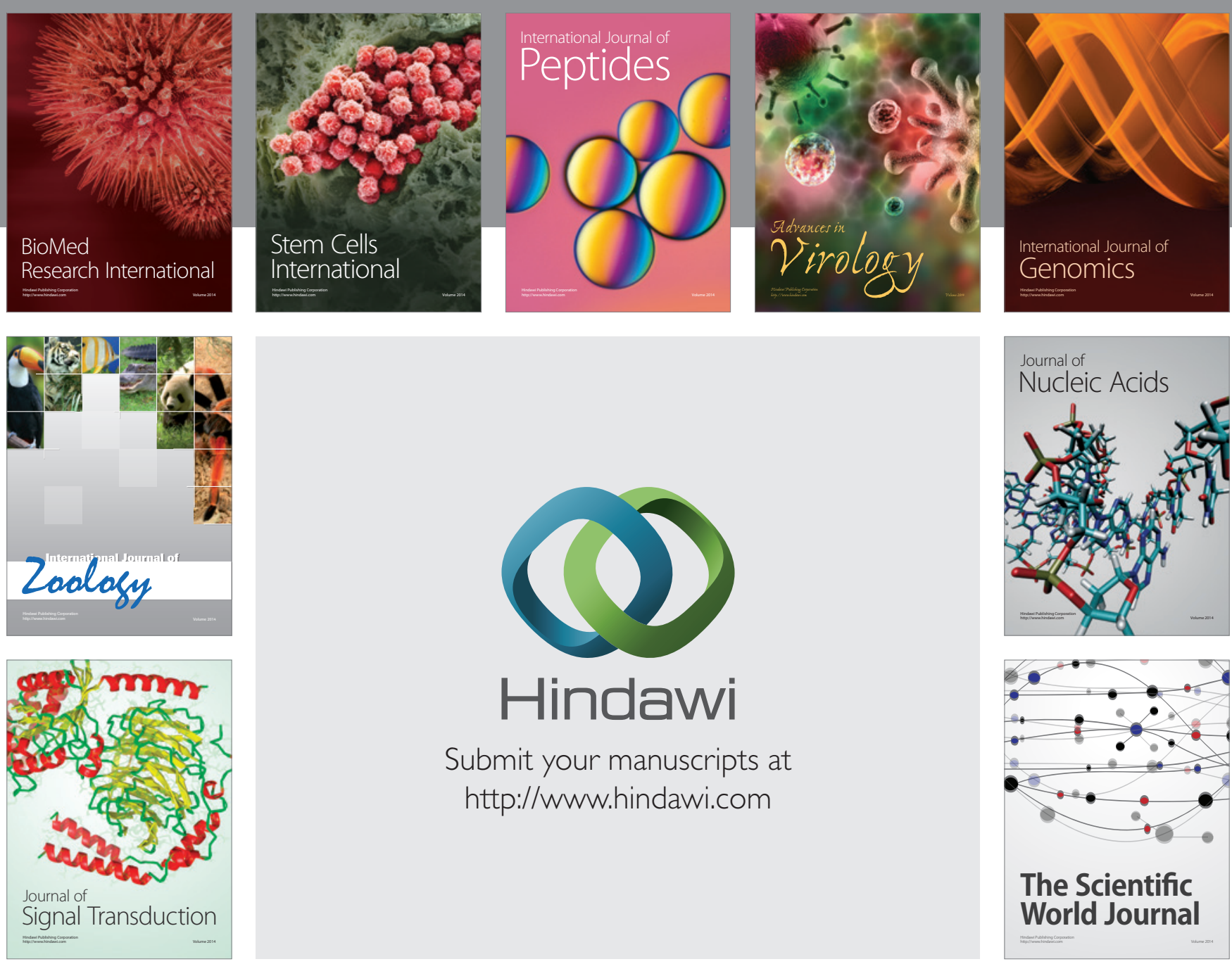

Submit your manuscripts at

http://www.hindawi.com
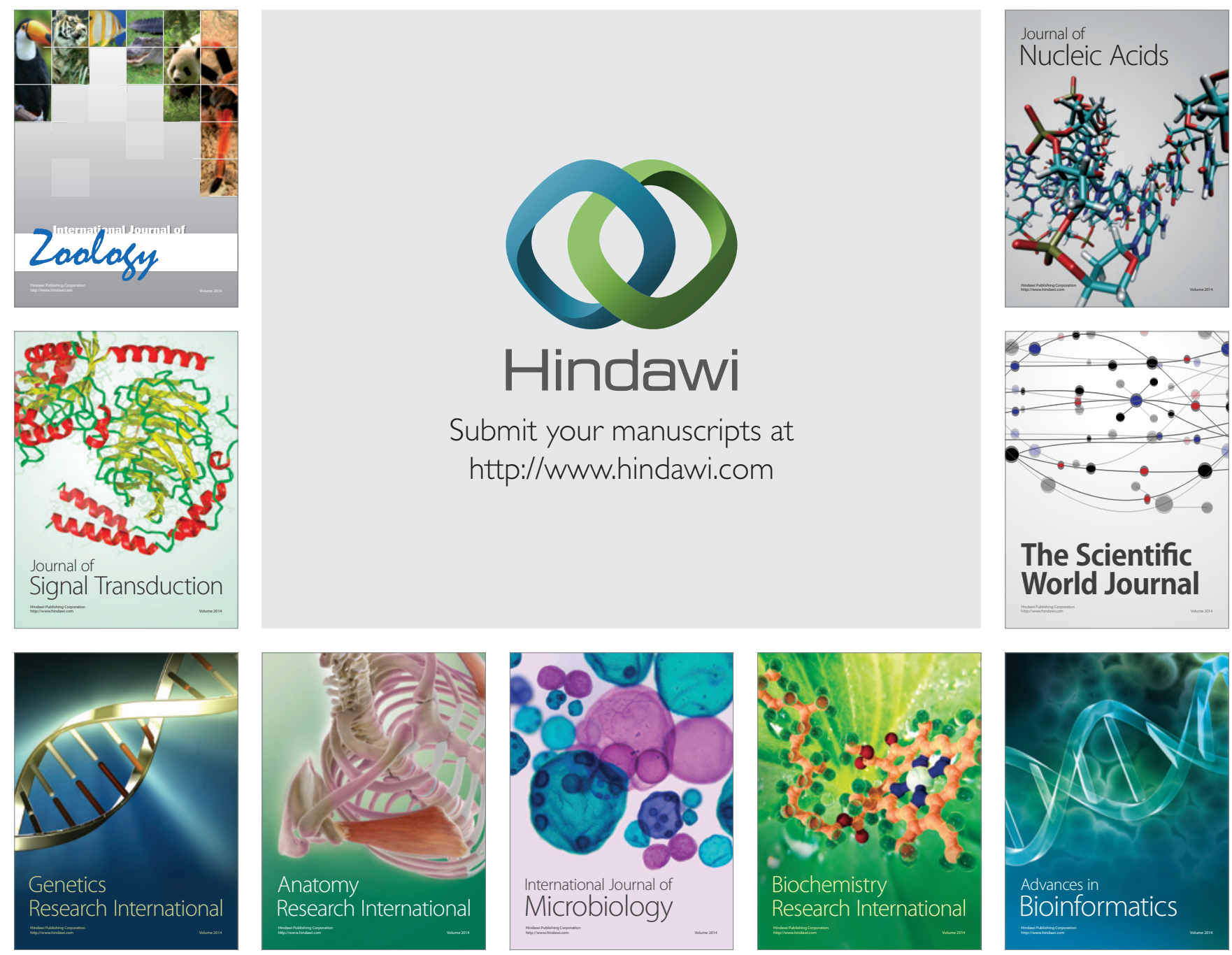

The Scientific World Journal
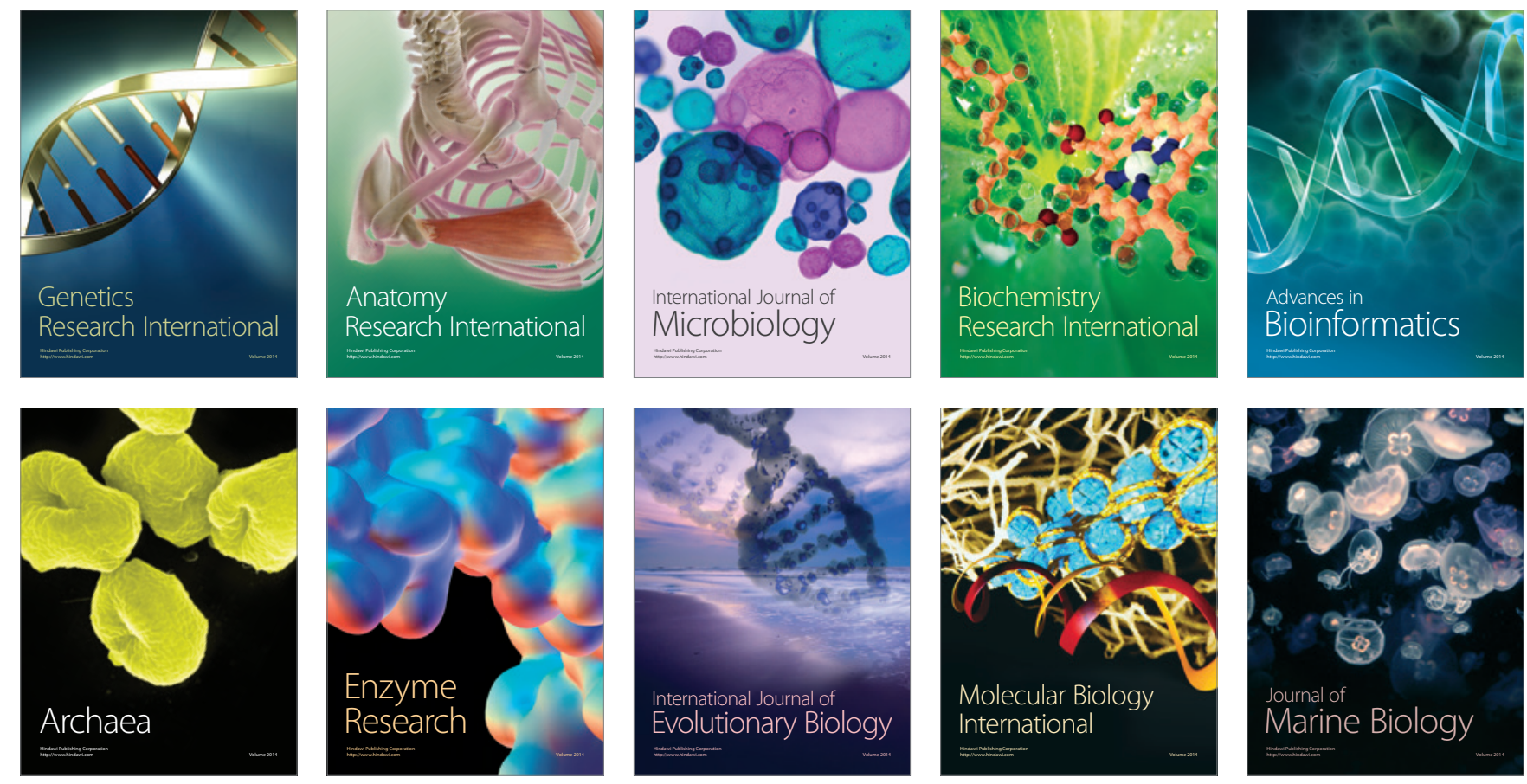